International Research Journal of Management, IT \& Social Sciences
Available online at https://sloap.org/journals/index.php/irjmis/
Vol. 6 No. 3, May 2019, pages: $29 \sim 36$
ISSN: 2395-7492
https://doi.org/10.21744/irjmis.v6n3.626

\title{
Comparative Analysis of Company Market Reactions on Right Issue for Pay Debt and Investment
}

Putu Sri Arta Jaya Kusuma a

Gerianta Wirawan Yasa ${ }^{b}$

Article history:

Received: 27 December 2018

Accepted: 31 March 2019

Published: 24 April 2019

\section{Keywords:}

abnormal return;

investment;

market reactions

right issue;

signaling theory;

\begin{abstract}
The right issue is the issuance of new shares conducted by companies where the right to buy new shares is given to the old shareholders. Funds from the rights issue can be used by companies for various purposes, namely paying off debt and investment. In this study wanted to test the market reaction to the announcement of the rights issue aimed at paying off debt and rights issues aimed at investment and comparing the market reaction to the rights issue aimed at paying off debt and investment. The research was conducted on companies listed on the Indonesia Stock Exchange (IDX) and which issued rights issues in 2015-2017 with a sample of 76 rights issues. The analysis techniques used were one sample t-test and independent sample t-test. Based on the results of the study, it was found that there was a positive market reaction to the rights issue aimed at investment. Whereas in the rights issue aimed at paying debt there is no market reaction. This research also proved that there was no difference in the market reaction to the rights issue aimed at paying off debt and investment.
\end{abstract}

2395-7492@ Copyright 2019. The Author. This is an open-access article under the CC BY-SA license (https://creativecommons.org/licenses/by-sa/4.0/) All rights reserved.

\section{Author correspondence:}

Putu Sri Arta Jaya Kusuma,

Faculty of Economic and Business, Udayana University, Bali,

Denpasar, Indonesia

Email address: jayajaje@gmail.com

\section{Introduction}

Every investor who invests his capital hopes to get a return on the investment made. Investors really need information from the capital market so that investors can make rational decisions to invest and investors can estimate the profits that will be obtained if they invest in a company that has been listed on the capital market (Yusuf, 2009). The purpose of investors to invest in the capital market is to obtain a reward or income from the funds invested (Marlina, 2012). All information available on the market can influence investors in making decisions.

One of the information that can influence investors in making decisions is the right issue. The right issue is a right where the old shareholders have the right to get new shares of the company so that the percentage of share ownership

${ }^{\text {a }}$ Faculty of Economic and Business, Udayana University, Bali, Indonesia

${ }^{\mathrm{b}}$ Faculty of Economic and Business, Udayana University, Bali, Indonesia [geri_wirasa@unud.ac.id] 
is not reduced. Old shareholders who want to maintain or actively participate in controlling the company, they will buy the rights issue. Old shareholders who don't want to get too into the company's control, the old shareholders will not buy the right issue (Medeiros, 2005). Right issues are usually issued at prices cheaper than market prices, this is intended as an incentive for the old shareholders. The issuance of the rights issue will make the old shareholders more interested in increasing the number of shares in the company which will make the old shareholders have greater voting rights at each General Meeting of Shareholders than if the rights issue is not redeemed (Raja, 2012). Funds from the rights issue can be used by the company for two purposes, namely investment and paying the debt.

The right issue that aims to pay off debt will cause a negative reaction by the market. While the positive issue of rights issues such as increasing working capital and developing investment will be responded positively by the market and old shareholders. Right issue aimed at investment will lead to market confidence because the funds collected from the results of the rights issue will provide benefits in the future. Medeiros (2005), states that there are differences in abnormal returns before and after the right issue because it is considered that the announcement of the rights issue is positive information for the old shareholders. This causes the market to react with a positive abnormal return. On the contrary, a rights issue that aims to repay the debt will cause the market to react negatively. Fahmi (2013), found that the company's profitability ratio after two years of conducting a rights issue did not experience a significant increase. This is probably due to the results of the rights issue to finance long-term investments that cannot be seen in a twoyear period or use these funds to pay debts due.

Bashir (2013), states that there are significant differences in abnormal returns before and after the announcement of the right issue conducted by the company. Yusuf (2009), stated that there were differences in the average abnormal return before and after the announcement of the rights issue because the old shareholders assumed that with the right issue the company would operate better than before.

The Miglani (2011) and Marisetty (2008), the study showed that stock returns moved positively after the announcement of the rights issue. Yusuf (2009), found that there was a significant difference between stock returns in the pair before and after the announcement of the rights issue, whereas for stock returns in the period pairs before and after producing a conclusion there were no significant differences. Hartono (2008), states that there are differences in average stock returns before and after the announcement of the rights issue. Stock returns declined after the announcement of the rights issue. These findings indicate that the possibility of information on the right issue has been absorbed in the days before the announcement, so that there is a significant change in return before the announcement day or maybe before the information is published, investors have made a reaction (improperly) first by short selling because investors' perception of falling prices after the rights issue. Marisetty (2008), also found that the market reaction to the announcement of rights issues was significantly different from zero. Suresha (2012); Sugiana (2013); Yanti (2012); Mulatsih (2009); Noraini (2009); Widaryanti (2006) and Susanti (2008), Ghosh (2017), stated that there were no significant differences in abnormal returns before and after the announcement of the rights issue because holders the old stock is of the view that the rights issue is not important information for the performance of the shares. Armitage (1998), found that rights issues generate negative reactions and give signals of overvaluation. Previous research shows the results of different market reactions to rights issues. This is probably due to differences in the objectives of the rights issue.

Previous research that shared market reactions based on the objectives of the right issue has not been done so much that in this study tried to compare the market reaction of the rights issue which aims to pay debts with a rights issue aimed at investment.

\section{Literature Review}

The Market Reactions to Right Issue for Pay Debt

Right issues aimed at restructuring debt can cause the market to react negatively. The company issued a rights issue that will be used to pay off its obligations, from the investor's side it will not be interested in investing (Sukwadi, 2006). Information on the use of right issue funds can be a signal for investors in making decisions (Aryasa, 2017). The right issue that aims to pay off debt is often regarded as negative information by investors. This is because paying a debt is deemed not to generate income in the future. If only to pay the debt, this sends a signal to the market that management has difficulty paying a debt or is burdened with a high-interest burden (Sukwadi, 2006). This is very reasonable because investors will hesitate to invest in companies that do not provide profits and have a high debt burden.

H1a: There is a negative market reaction to the rights issue that aims to pay off debts around the announcement.

$\mathrm{H} 1 \mathrm{~b}$ : There is a negative market reaction to the rights issue that aims to pay off debts around the cum date. 
The Market Reactions on Right Issues for Investment Purpose

Yusuf (2009) stated that there were differences in the average abnormal return before and after the announcement of the rights issue because the old shareholders assumed that with the right issue the company would operate better than before. Medeiros (2005) and Kithinji (2014) state that there are differences in abnormal returns before and after the right issue because it is assumed that the announcement of the rights issue is positive information for the old shareholders. The right issue is positive if the funds obtained are invested in the project, especially those that promise high returns, be it new investment projects or increased working capital (Sukwadi, 2006).

$\mathrm{H} 2 \mathrm{a}$ : There is a positive market reaction to the rights issue that aims to invest in the announcement.

$\mathrm{H} 2 \mathrm{~b}$ : There is a positive market reaction to the right issue that aims to invest around the cum date.

\section{The Market Reaction Differences in Right Issue for Pay Debt and Investment}

Based on the results of previous studies there are inconsistent research results. This might be due to differences in investor reactions based on the objectives of the rights issue. The market will give a positive market reaction to good news and negative reactions to bad news (Aryasa, 2017). For investors and companies, the issuance of new shares is positive if the funds are used for business expansion/expansion that will be profitable in the future and the issuance of negative new shares if the funds are used to overcome financial difficulties in order to pay the obligations of the company that will mature (Sukwadi, 2006).

The right issue does not always cause a negative reaction. If the right is expected to be able to raise funds for investment and business expansion purposes, then the right can be a positive signal and give investors hope for future profits.

H3a: There are differences in market reactions in the rights issue aimed at paying debt and rights issues aimed at investing around the announcement.

$\mathrm{H} 3 \mathrm{~b}$ : There are differences in market reactions in the rights issue aimed at paying off debts and rights issues aimed at investing around the cum date.

\section{Materials and Methods}

This research was conducted at companies listed on the Indonesia Stock Exchange (IDX) which can be accessed through the site www.britama.co.id and finance.yahoo.co.id in the form of rights issue objectives and daily closing prices of shares. This study uses data from the period $2015-2017$ by using a sampling method with non-probability sampling, namely saturated sampling where all members of the population are included in the sample. The research sample was 76 announcements of rights issues during 2015-2017, with a division of 60 rights issues aimed at investment and 16 rights issues aimed at paying off debt. The data analysis technique used to test the hypothesis in this study is the one sample t-test and man and Whitney test analysis models. One sample t-test was used to test H1 and H2 while H3 was tested using man and Whitney test.

\section{Results and Discussions}

\subsection{The Market Reactions to Right Issue for Pay Debt}

Table 1

One Sample t-test

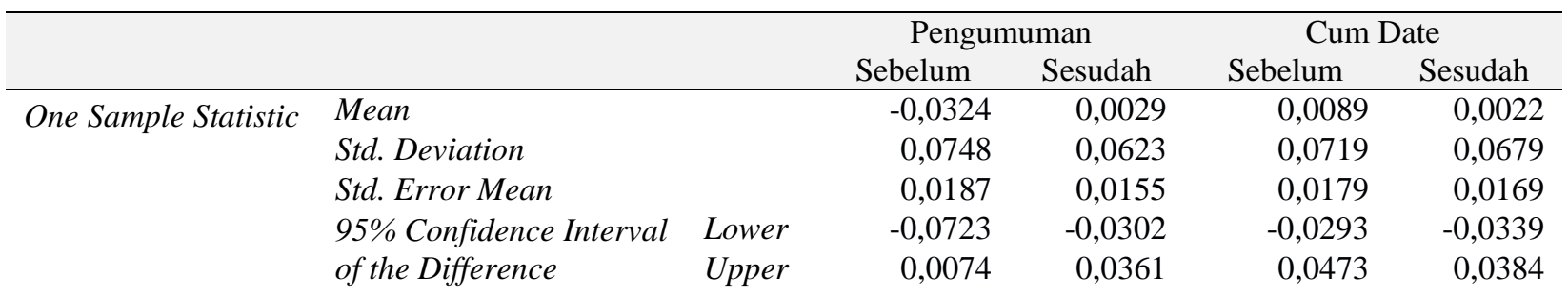

Kusuma, P. S. A. J., \& Yasa, G. W. (2019). Comparative analysis of company market reactions on right issue for pay debt and investment. International Research Journal of Management, IT and Social Sciences, 6(3), 29-36. 


\begin{tabular}{lrrrr}
$\mathrm{t}$ & $-1,735$ & 0,189 & 0,499 & 0,131 \\
Df & 15 & 15 & 15 & 15 \\
sig. (2-tailed) & 0,103 & 0,853 & 0,625 & 0,897 \\
\hline
\end{tabular}

Primary Data, 2018

Table 1 shows sig. values. (2-tailed) 0.103 before the announcement and 0.853 after the announcement. Sig value (2tailed) 0.625 before cum date and 0.897 after cum date. This value states that there is no negative market reaction in the company that made the announcement of the rights issue aimed at paying the debt because of sig. (2-tailed) $0.853>$ 0.05 after the announcement and 0.625>0.05 around the cum date. Sig value (2-tailed) also stated that H1a and H1b were rejected. Widaryanti (2006) states that there is no difference in abnormal returns before and after the right issue because investors assume that the rights issue is a matter of course. The absence of a significant reaction is possible because the information on the rights issue is not strong enough to be accepted by the market. In addition, the objective of the right issue to pay off debt is not all received well by investors because it is considered to be able to facilitate the performance of the company with reduced debt. This result also proves that investors are not interested in the rights issue that will be used to pay the debt. The old shareholders also thought that not taking their rights does not mean that they must release their shares. Old shareholders also still want to hold their shareholding by looking at other factors beyond the purpose of the rights issue.

\subsection{The Market Reactions on Right Issues for Investment Purpose}

Table 2

One Sample t-test

\begin{tabular}{|c|c|c|c|c|c|c|}
\hline & & & Annour & ent & $\mathrm{Cu}$ & \\
\hline & & & Before & After & Before & After \\
\hline & Mean & & 0,0094 & 0,0310 & 0,0323 & 0,0369 \\
\hline One Sample Statistic & Std. Deviation & & 0,0642 & 0,1139 & 0,1244 & 0,1911 \\
\hline & Std. Error Mean & & 0,0082 & 0,0147 & 0,0160 & 0,0246 \\
\hline & $\begin{array}{l}95 \% \text { Confidence Interval } \\
\text { of the Difference }\end{array}$ & Lower & $-0,0071$ & 0,0015 & 0,0002 & $-0,0124$ \\
\hline & & Upper & 0,0260 & 0,0604 & 0,0645 & 0,0863 \\
\hline $\mathrm{t}$ & & & 1,136 & 2,107 & 2,016 & 1,497 \\
\hline Df & & & 59 & 59 & 59 & 59 \\
\hline sig. (2-tailed) & & & 0,261 & 0,039 & 0,048 & 0,140 \\
\hline
\end{tabular}

Primary Data, 2018

Table 2. shows the value of sig. (2-tailed) 0.261 before the announcement and 0.039 after the announcement. Sig value (2-tailed) 0.048 before and 0.140 after cum date. The positive t value is 2.107 after the announcement and 2.016 before the cum date. This value states that there is a positive market reaction in companies that make announcements of rights issues aimed at investment because of sig. (2-tailed) $0.039>0.05$ after the announcement. Sig value (2-tailed) states that $\mathrm{H} 2 \mathrm{a}$ is accepted. The right issue is positive if the funds obtained are invested in the project, especially those that promise high returns, be it new investment projects or increased working capital (Sukwadi, 2006). Investors have the view that the purpose of using funds for investment promises future profits.

\subsection{The Market Reaction Differences in Right Issue for Pay Debt and Investment}

Table 3.

Man and Whitney test

\begin{tabular}{|c|c|c|}
\hline & Announcement & Cum Date \\
\hline Mann-Whitney U & 438,000 & 409,000 \\
\hline Wilcoxon W & 574,000 & 545,000 \\
\hline $\mathrm{Z}$ & $-0,535$ & $-0,905$ \\
\hline Asymp. Sig. (2-tailed) & 0,593 & 0,366 \\
\hline
\end{tabular}

Primary data, 2018 
Table 3 shows the value of sig. (2-tailed) of $0.539>0.05$ at the time of announcement and 0.366>0.05 at the time of cum date. This value states that $\mathrm{H} 3 \mathrm{a}$ and $\mathrm{H} 3 \mathrm{~b}$ are rejected. This value also states that there is no significant difference in abnormal return of shares in companies that make announcements of rights issues aimed at investing with rights issues aimed at paying debts around announcements and cum dates. Because $\mathrm{H} 3 \mathrm{a}$ and $\mathrm{H} 3 \mathrm{~b}$ are rejected, $\mathrm{H} 3$ is rejected. Investors also see company performance factors as a consideration in buying shares. Companies with poor performance even though issuing rights issues aimed at investment will not attract investors to buy their shares. The results of this study are also influenced by the presence of homogeneous data which may be due to the number of shares that are less glanced by investors.

\section{Conclusion}

There was no negative market reaction to the company that made the announcement of the rights issue aimed at paying off debt. This means that the announcement of the rights issue aimed at paying the debt was not responded by investors so that there was no significant market reaction. This result shows that the rights issue that aims to pay off debt as a whole is not strong enough to influence the old shareholders to release their shares. There is a positive market reaction for companies that make announcements of rights issues aimed at investment. Announcement of rights issues aimed at investment was responded to by investors so that there was a market reaction around the announcement date. This shows that the announcement of the rights issue aimed at investment is considered as important information for investors. There is no difference in the average stock abnormal return in companies that make announcements of rights issues aimed at investing with rights issues aimed at paying off debt. This is due to a large number of homogeneous data which may be caused by many stocks that are less glanced by investors issuing rights issue policies. In addition, the number of samples that differ greatly between rights issues aimed at an investment with rights issues aimed at paying debt also influences the results of the research.

\section{Suggestion}

Old shareholders should reconsider the decision to use rights right by looking at the company's objectives in issuing rights issue policies. Old shareholders should also look at other factors besides the purpose of the right issue, considering that there is no significant difference in abnormal returns in the right issue aimed at investing by paying the debt.

For prospective investors to consider carefully before investing in companies that issue rights issue policies by looking at the company's objectives to issue rights issue policies. Based on the results of the study there is a positive abnormal return on the right issue aimed at investment. Investors look more at rights issues that aim at investment than rights issues that aim to pay off debt because they are considered to be able to produce results in the future. Prospective investors should also look at other factors besides the purpose of the right issue, considering that there is no difference in abnormal returns in the rights issue aimed at investing by paying the debt. Prospective investors can consider other companies that issue other policies besides the rights issue.

Issuers need to reconsider the decision to conduct a rights issue. Issuers also need to clarify the objectives of the right issue so that it can be accepted by old shareholders and investors widely.

\section{Further Research}

For further researchers to examine more about the rights issue is not only limited to the objectives of the rights issue but also to the size of the company. Large companies will still be looked at by investors regardless of the purpose of the rights issue issued. Whereas small companies are less able to convince investors even though they issue rights issues aimed at investment. In this research, this cannot be done because the number of samples in the right issue aims to pay too little debt.

\section{Conflict of interest statement and funding sources}

The authors declared that they have no competing interest. The study was financed by personal funding.

Kusuma, P. S. A. J., \& Yasa, G. W. (2019). Comparative analysis of company market reactions on right issue for pay debt and investment. International Research Journal of Management, IT and Social Sciences, 6(3), 29-36. 
Statement of authorship

The authors have a responsibility for the conception and design of the study. The authors have approved the final article.

Acknowledgments

The authors would like to acknowledge the editor of IRJMIS for their support, valuable time, and advice in completing the present article. 
References

Armitage, S. (1998). Seasoned equity offers and rights issues: a review of the evidence. The European Journal of Finance, 4(1), 29-59. https://doi.org/10.1080/13518479800000002

Aryasa, I. P. G. C. A., \& Suaryana, I. A. Reaksi pasar sebelum dan sesudah pengumuman right issue. E-Jurnal Akuntansi, 1426-1454.

Bashir, A. (2013). Impact of Right Issues Announcement on Shareholders Wealth: Case Study of Pakistani Listed Companies. International Journal of Contemporary Business Studies, 4(3).

Fahmi, I. (2012). Manajemen Investasi: Teori dan Soal Jawab. Jakarta: Salemba Empat.

Fahmi, I., \& Saputra, M. (2011). Analysis of financial performance in a form of financial ratio before and after right issue at the indonesia's stock exchange (bursa efek indonesia). International Journal of Business and Social Science, 2(24).

Fahmi, I., \& Saputra, M. (2013). Analysis of Profitability Ratio in Publishing Right Issue Decision at Indonesia Stock Exchange. International Journal of Business and Social Science, 4(4).

Ghosh, C. (2017). A study on - evaluating marketing strategies adopted by home appliance for economic development in India. International Journal of Social Sciences and Humanities, 1(1), 9-15. https://doi.org/10.29332/ijssh.v1n1.7

Hartono, D., \& Resosudarmo, B. P. (2008). The economy-wide impact of controlling energy consumption in Indonesia: An analysis using a Social Accounting Matrix framework. Energy Policy, 36(4), 1404-1419. https://doi.org/10.1016/j.enpol.2007.12.011

Kithinji, J. G., Oluoch, W., \& Mugo, R. (2014). What Is the Effect of Rights Issue on Firms Share Performance in the Nairobi Securities Exchange?.

Marisetty, V. B., Marsden, A., \& Veeraraghavan, M. (2008). Price reaction to rights issues in the Indian capital market. Pacific-Basin Finance Journal, 16(3), 316-340. https://doi.org/10.1016/j.pacfin.2007.07.002

Marlina, S., \& Riau, J. A. U. Perbedaan capital gain sebelum dan sesudah pengumuman right issue pada perusahaan property, real estate dan building construction yang terdaftar di bei 2008-2011.

Medeiros, O. R. D., \& Matsumoto, A. S. (2005). Brazilian market reaction to equity issue announcements. Revista de Administração Contemporânea, 9(SPE2), 36-46. http://dx.doi.org/10.1590/S1415-65552005000600004

Miglani, P. (2011). An empirical analysis of impact of right issues on shareholders returns of Indian listed companies. Researchers World, 2(4), 169.

Mulatsih, L. S., \& Harry-Susanto, M. (2009). Analisis Reaksi Pasar Modal Terhadap Pengumuman Right Issue di Bursa Efek Jakarta (BEJ)(Pengamatan Terhadap Return, Abnormal Return, Security Return Variability dan Trading Volume Activity). WACANA, Jurnal Sosial dan Humaniora, 12(4), 646-661.

Naidu, G. (2012). An empirical study on announcement effect of right Issue on share price volatility and liquidity and its Impact on market wealth creation of informed Investors in Bangalore with special reference to CNX Nifty stocks of NSE. EXCEL International Journal of Multidisciplinary Management Studies, 2(7), 41-58.

Noraini, A. (2009). The Post-Issue Performance of Rights Issues in Malaysia (Doctoral dissertation, Universiti Utara Malaysia).

Raja, A. (2012). Right Issues and Price Behaviour: Indian Evidence. Indian Journal of Research, 1(9).

Sugiana, B., \& Surya, B. A. (2013). Implication of Right Issue Cum and Ex-Date Announcement to the Stock Return (Empirical Study on Indonesia Stock Exchange Period: 2009-2012). Indonesian Journal of Business Administration, 2(12).

Sukwadi, R. (2006). Analisis Perbedaan Kinerja Keuangan Perusahaan yang Melakukan Right Issue dan Perusahaan yang Tidak Melakukan Right Issue di Bursa Efek Jakarta Periode 2000-2003 (Doctoral dissertation, program Pascasarjana Universitas Diponegoro).

Susanti, I. Analisis hubungan dan perbedaan abnormal return sebelum dan sesudah right issue.

Widaryanti. (2006). Perbedaan Antara Sebelum dan Sesudah Pengumuman Right Issue Terhadap Abnormal Return dan Trading Volume Activity pada Perusahaan Publik di Bursa Efek Jakarta. Fokus Ekonomi, 1(1), 38-46.

Yanti, F. (2013). Pengujian Abnormal Return Saham Sebelum dan Sesudah Peluncuran Indeks Saham Syariah Indonesia (ISSI). Jurnal Kajian Manajemen dan Wirausaha, 1(01).

Yanti, T. S. (2007). Uji Rank Mann-Whitney Dua Tahap. Statistika: Journal of Theoretical Statistics and Its Applications, 7(1).

Yusuf, S. D., Djazuli, A., \& Susanto, H. M. H. (2009). Analisis reaksi investor terhadap rengumuman right issue di bursa efek Jakarta Wacana, 12(4).

Kusuma, P. S. A. J., \& Yasa, G. W. (2019). Comparative analysis of company market reactions on right issue for pay debt and investment. International Research Journal of Management, IT and Social Sciences, 6(3), 29-36.

https://doi.org/10.21744/irjmis.v6n3.626 


\section{Biography of Author}

\begin{tabular}{|l|l|} 
Putu Sri Arta Jaya Kusuma was born in Denpasar. He finished his study at Master \\
Accounting in Udayana University. He is interested in the accounting field. \\
Email: jayajaje@ gmail.com
\end{tabular}

